\title{
DERMATOLOGY AND PSYCHOSOMATICS
}

This new journal was set into motion at the beginning of the year 2000. It is a genuine child of the 21st century. Its professed aim is to establish a dialogue between dermatology and psychosomatics, psychiatry and psychology.

I recently returned from the annual meeting of the Association of Psychocutaneous Medicine of North America (APMNA), held before the annual congress of the American Academy of Dermatology (AAD). The meeting provided stimulating contributions for this second issue of the new journal.

DERMATOLOGY AND PSYCHOSOMATICS aims to be an international journal presenting scientific papers from dermatology and psychosomatic medicine, psychiatry and psychology, especially those bridging these fields. The present issue proves that we are on the right track.

It contains one review and three original papers together with one case report and information from four different countries, demonstrating that psychosomatic dermatology has become an important pillar of dermatology. With DERMATOLOGY AND PSYCHOSOMATICS, we are among the pioneers bringing different faculties and fields together.

It is my special honor to welcome Professor Emiliano Panconesi of Florence as one of the editors-in-chief of this journal. Professor Panconesi submitted an overview entitled 'Epistemological Aspects of Psychosomatic Dermatology'. $\mathrm{He}$ is the President of the European Society of Dermatology and Psychiatry (ESDaP) and one of the most famous psychosomatic dermatologists in the world. Panconesi proposes an epistemology of psychosomatic dermatology - which is surely a difficult task. I am confident that his paper will stimulate an intensive discussion on theoretical approaches to psychosomatic dermatology. Panconesi's article outlines the essentials of his well-known book 'Stress and Skin Disease' [2].

The original articles in this issue deal with quite different but nevertheless very important topics. The first is a paper on stress reactions and psoriasis in Bosnian soldiers compared to civilians. This very recent study can explain the development and, more importantly, the relapse of psoriasis under life-long and, perhaps, even life-threatening stress conditions. Suljagic, the first author, was awarded a poster prize at the last International Congress on Dermatology and Psychiatry in Paris in 1999.

Another paper from Turkey deals with depression, anxiety and anger, suggesting that anger is not a common problem in patients with acne. The study shows the importance of looking for predictors or sub-groups of patients who suffer from acne of different grades of severity, as was done by Kellett and Gawkrodger [1]. These authors found significant levels of anxiety in $44 \%$ of patients and significant depression in $18 \%$. The predictors of quality of life in atopic eczema patients is the topic dealt with by Lange and co-workers from the Freiburg Psychodermatologic Research Group. The quality of life seems to have become the primary target variable in therapy evaluation studies. The authors were able to demonstrate a significant correlation with other questionnaires. Although quality of life seems easy to measure, we recognize very different emotional influences from a psychodynamic as well as from a behaviorally oriented level.

Finally, Burkard Brosig presents one of his very interesting case studies which gets 'under one's skin'. Urticaria is, in my opinion, the prime example of a psychosomatic skin manifestation, and I do hope that the journal will receive more articles on this topic.

The editors hope you will enjoy the new journal DERMATOLOGY AND PSYCHOSOMATICS. We invite you to send us your comments, criticisms, opinions and 'letters to the editor'. That will enable us to further refine our services for you, our readers.

Uwe Gieler, Gießen

\section{References}

1 Kellett SC, Gawkrodger DJ: The psychological and emotional impact of acne and the effect of treatment with isotretinoin. Br J Dermatol 1999;140:273-282.

2 Panconesi E: Stress and Skin Disease: Psychosomatic Dermatology. Clinics in Dermatology. Philadelphia, PA, Lippincott, 1984.

\begin{tabular}{ll}
\hline KARGER & $\oplus$ 2000 S. Karger GmbH, Freiburg \\
$\begin{array}{l}\text { Fax }+497614520714 \\
\begin{array}{l}\text { E-mail Information@Karger.de } \\
\text { www.karger.com }\end{array}\end{array}$ & Accessible online at: \\
www.karger.com/journals/dps
\end{tabular}

